May 2012

\title{
International Legal Collections at U.S. Academic Law School Libraries
}

Camelia Naranch

San Jose State University, cnaranch@gmail.com

Follow this and additional works at: https://scholarworks.sjsu.edu/ischoolsrj

Part of the Library and Information Science Commons

\section{Acknowledgements}

This article originated as a final research project for Professor Jean Bedord's fall semester 2011 graduate course, Information and Society (LIBR 200-05). I would like to thank Prof. Bedord for her suggestions, insights, and criticism. I am also grateful to the other students in the course for sharing their own research and thoughts via on-line discussion boards over the course of the semester.

\section{Recommended Citation}

Naranch, C. (2012). International Legal Collections at U.S. Academic Law School Libraries. School of Information Student Research Journal, 2(1). https://doi.org/10.31979/2575-2499.020106 Retrieved from https://scholarworks.sjsu.edu/ischoolsrj/vol2/iss1/6

This article is brought to you by the open access Journals at SJSU ScholarWorks. It has been accepted for inclusion in School of Information Student Research Journal by an authorized administrator of SJSU ScholarWorks. For more information, please contact scholarworks@sjsu.edu. 


\title{
International Legal Collections at U.S. Academic Law School Libraries
}

\begin{abstract}
This study examines how law librarians are participating in the process of creating new fields of international legal research and training. It investigates the current state of international legal collections at twelve public and private U.S. academic law school libraries, illuminating in the process some of the significant shifts that characterize the nature of professional librarianship and information science in the twenty-first century. Included in the study is a discussion of the reference works, research guides, and databases that make up these international legal collections. This is followed by a brief assessment of the trends and challenges that librarians face who work in the field of professional legal education and scholarship.
\end{abstract}

\section{Keywords}

academic law libraries, collection development, foreign legal databases, globalization, international law databases, international legal collections, international legal librarianship, law school curriculum, legal databases, legal education

\section{Acknowledgements}

This article originated as a final research project for Professor Jean Bedord's fall semester 2011 graduate course, Information and Society (LIBR 200-05). I would like to thank Prof. Bedord for her suggestions, insights, and criticism. I am also grateful to the other students in the course for sharing their own research and thoughts via on-line discussion boards over the course of the semester.

\section{About Author}

Camelia Naranch is a serials specialist at the Robert Crown Law Library at Stanford University and an MLIS student at San Jose State University. She may be contacted at cnaranch@law.stanford.edu. 


\section{International Legal Collections at U.S. Academic Law School Libraries}

Over the course of the past two decades, the process of globalization has had a dramatic impact on legal education in the United States (U.S.). Leading academic law schools now offer a wide range of courses in foreign, comparative, and international law. In response to dynamic changes happening on a global scale, a number of these schools are currently developing innovative new programs dedicated to specific topics, such as global business, human rights, environmental protection, international migration, and international conflict resolution. Law school librarians who have been involved with their development have consistently maintained that in order for these programs to be successful, the existing international legal collections at law school libraries will need to be transformed using new technology and Internet-based search tools. The past few years have witnessed a dramatic growth in the number of online legal guides and databases specifically dedicated to organizing relevant materials for the purposes of international legal research (Rumsey, 2008b). While international legal collections at U.S. academic law schools remain partially in print format, the most striking aspect of their current state is how much material is currently available on-line.

This study examines how law librarians are participating in the process of creating new fields of international legal research and training. It investigates the current state of international legal collections at twelve public and private U.S. academic law school libraries, illuminating in the process some of the significant shifts that characterize the nature of professional librarianship and information science in the twenty-first century. In theory as well as in practice, librarians at the law schools investigated in this study are supporting the efforts of legal scholars to make the study of foreign, comparative, and international law (often abbreviated as FCIL) an integral part of U.S. academic legal education. They remain active participants in the process in three major ways. First, librarians teach international legal research courses that train students in how to locate and evaluate sources. Second, librarians create and maintain the collections on which the new FCIL programs rely. They oversee a complex transition process from predominately print to mainly electronic materials and make decisions on which sources from their older collections to digitize. They also build and provide access to databases that contain current and historical legal information from around the world. Third, to help navigate through these large data collections, librarians design and maintain online legal research guides. These guides are the gateways that students and scholars use to conduct research quickly, effectively, and successfully.

The following investigation of the current state of international legal collections at a variety of public and private U.S. academic law school libraries 
highlights some of the significant shifts that characterize the nature of professional librarianship and information science in the twenty-first century. Above all, it shows how dramatically the Internet has impacted the day-to-day operations of the modern library. It offers concrete evidence that libraries today are no longer just physical repositories of books, magazines, and on-site data. They are rapidly becoming powerful nodes in global digital networks of searchable and useful information essential for a growing number of professions. The routine work of law librarians now involves integrating electronic information and online search tools into their present collections. In the process, they must overcome the challenge of organizing enormous amounts and types of information that exists in multiple languages and is dispersed across a global landscape.

\section{The New International Legal Landscape}

First-year law students at a growing number of top-ranked U.S. schools will not find a single, all-inclusive course in international law in which to enroll. Instead, if these students are studying at Bay area locations like Berkeley or Stanford, or are enrolled at Georgetown, Harvard, Columbia, Chicago, Syracuse, or Duke, they will find a range of courses, programs, and clinics grouped together under the name of FCIL. These curricula cover a wide range of topics, from environmental regulations and corporate governance to international war crimes and refugee applications for asylum. When these students start work on their first research papers, they may well begin with a trip to their law school library, but not to spend hours on end reading weighty volumes of foreign legal codes and court decisions, buried under a mass of books, papers, and periodicals. They are more likely to head for the reference desk, where an international legal librarian might direct them to a particular online database, walk them through the steps outlined in a web-based research guide, or help them use the Internet to translate the foreign language sources that they find. The librarian might even be one of the student's instructors who lectures on international legal research methods as part of the programs offered and taught by members of the law school faculty.

Although these students may not be aware of it, they will be the first generation of American-trained lawyers to pass through programs of study in which foreign, comparative, and international law are integral parts of their professional training. Even if they never intend to practice law outside of the United States, they are likely to encounter clients and confront issues that are global in nature (Silver, Van Zandt, \& De Bruin, 2008). These students also might choose career paths in a growing array of legal specialties, from international human rights advocacy to global business, for which advanced training and extensive exposure to international legal sources are essential. 
As Friedman (2011) points out, most laws in the world remain local and domestic in nature. As a profession, law was less affected by earlier phases of globalization than was business. Until recently, international law was a specialized form of knowledge taught at U.S. law schools but only in a limited manner. Now, the situation is being transformed by schools like Harvard University, which have recognized the impact of globalization on the legal profession and taken rapid steps to reinvent their curriculum. Harvard offers more than 90 courses and reading groups focusing on foreign, international, and comparative law. Students can now take seminars in Asian or Middle Eastern law, for example, or intern with the Greater Boston Legal Services and work with immigrants and refugees seeking asylum. Harvard characterizes its approach well on their International Legal Studies website by referring to an international perspective as "foundational, rather than peripheral, to legal inquiry" (Harvard Law School, 2011). At Georgetown University, all first-year students now take an intensive one-week class at the start of their program called "Law in Global Context" that introduces them to a specific topic, such as extradition treaties or intellectual property rights (Georgetown University Law Center, 2011). Students at Cornell University can work with the Avon Global Center for Women and Justice, while those at U.C. Berkeley have the choice of programs offered by the Miller Institute for Global Challenges and the Law (Cornell University Law School, 2011; U.C. Berkeley School of Law, 2011).

\section{Legal Librarians and the Internet}

How did these programs and courses come about so quickly, and what informational resources currently exist to support them? The answer has a lot to do with librarians, and with the Internet. Creating the international legal collections to accompany the new programs of study was a major challenge, but also an opportunity, for librarians to demonstrate their abilities at managing very large amounts of data. In fact, law librarians began to discuss early in the process the potential of the Internet to assist them in building international legal collections. In 1991, the Library of Congress hosted a workshop that invited forty international participants active in producing, acquiring, editing, indexing, or distributing legislative information. The workshop was organized with the support of Harvard Law School Library, the New York Public Library, the United Nations Library, and a number of important public and private legal database providers, such as WestLaw and Lexis (Chiang \& Price, 1992). The following year, Harvard law librarian Harry S. Martin (1992) made a preliminary proposal for a cooperative online international legal index in which scholars and students could exchange copies of foreign legal materials using a combination of email and telefax delivery systems. 
These early initiatives helped set in motion a variety of pilot projects designed to test out the most effective means of sharing legal information across international borders. The development of the World Wide Web and improved hypertext transfer protocols in the mid-1990s greatly enhanced the abilities of legal scholars and librarians to share information using a simple click of the mouse. According to one roundtable panelist at the 1995 annual meeting of the American Society of International Law, "the beauty of the Web is that it provides instant, intuitive, hypertextual links and it will work on most computers with graphical interfaces, assuming, of course, software and hardware to connect to the Internet" (Zarins et al., 1995, p. 3). Such technological advances, the panelists realized, would create new possibilities for building the international legal collections at U.S. law schools.

Another proponent of the transformative potential of the Internet for international legal collection development was the New York University law librarian, Mirela Roznovschi. In an influential publication about the coming "cyberlegal culture" (2002), she observed that "in the www environment, we experience ubiquity, being in many different places simultaneously, and atemporality, being in an abstract time that overrides all global time zones" (p. 8). She was among the first reference librarians to create an online guide to international legal research, which was subsequently copied and refined by other librarians working at different U.S. law schools. At conferences, in books, and in academic journals, especially the International Journal of Legal Information and Legal Reference Services Quarterly, a number of participants in the process of creating such guides began to discuss their successes and strategies and offered suggestions for future development (Borgman, 2003; Germain, 2007; Haugen, 2005; Kimbrough, 2006).

As U.S. law schools began to implement their new approaches to teaching international law, a number of them established librarian-taught courses that familiarized students with the new search tools, online guides, and databases coming out at the time (Bird, 2011; Rumsey, 2009; Stanton, 2010). Currently, Duke Law School (2011) offers a course by Kristina Alayan on "Research Methods in International, Foreign, and Comparative Law." At Stanford Law School (2011), the equivalent course, taught by Sergio Stone, is called "Foreign and International Legal Research." The emergence of courses like these as part of law school FCIL curricula is reflective of a larger trend towards creating faculty and instructional opportunities for librarians who, in addition to MLS backgrounds, often are fluent in multiple languages and have JD or other advanced degrees. The emerging cyberlegal landscape owes a great deal to such individuals who are using their skills, experiences, and training to create the international legal collections that currently exist (Balleste, Luna-Lamas, \& Smith-Butler, 2007). 


\section{International Legal Collections in Practice}

There is at the present time no comprehensive analytical study of FCIL collections at public and private U.S. academic law schools. This study is based on an assessment of twelve leading U.S. law school libraries whose resources for research support advanced programs of study in the fields of foreign, comparative, and international law. These libraries were the Berkeley Law Library at the University of California - Berkeley; the Robert Crown Law Library at Stanford University; the Goodson Law Library at Duke University; the D'Angelo Law Library at the University of Chicago; the Edward Bennett Williams Law Library at Georgetown University; the Arthur W. Diamond Law Library at Columbia University; the Law Library at New York University; the H. Douglas Barclay Law Library at Syracuse University; the University of Iowa College of Law Library at the University of Iowa; the Lillian Goldman Law Library at Yale University; the Harvard Law School Library at Harvard University; and the Cornell Law Library at Cornell University. Because of its important and leading role in the development of FCIL collections, the study also included the U.S. Library of Congress in Washington, DC.

The international legal collections under investigation can be divided into three basic parts. These are: print sources, online research guides, and databases.

\section{Print Sources}

The first part of an international legal collection is print sources available to users at the libraries themselves. These include older materials, such as international law journals published in the late nineteenth and early twentieth centuries, in addition to more recently published monographs, conference proceedings, edited collections, and government documents. Researchers still rely upon printed materials, especially if they are interested in the history of foreign, comparative, and international law.

International legal researchers continue to rely upon printed reference works to familiarize themselves with new topics. One such example is the Guide to International Legal Research, which is published annually by the George Washington International Law Review (2011). Guides like this are helpful starting points for locating books, journal articles, documents, and databases on a wide range of topics organized both by country and theme. One recently added feature to the Guide is enhanced attention to Web-based sources, which are listed separately from print materials. In the case of intellectual property rights in Latin America, for example, the Guide lists an English-language reference work from 1997 as well as a more recent online bilingual database, INDECOPI (p. 665). The 
former is useful for studying the historical background while the latter is the better choice for current laws and regulations. Reference guides work in tandem with another important source consulted frequently at the start of new research, the international legal encyclopedia, especially the Max Planck Institute's Encyclopedia of Public International Law (Bernhardt, 1992). In 2008, a new editorial team began the laborious process of updating and revising this reference work, posting the initial essays online while preparing a complete print version for future publication. The new encyclopedia, which is overseen by the Max Planck Institute for Comparative Public Law and International Law in Heidelberg, Germany, contains peer-reviewed entries written by more than 800 legal experts from around the world. It is now available both as an on-line edition and as a tenvolume print set (Wolfrum, 2012).

\section{Online Research Guides}

The next major part of an international legal collection is an online research guide. While a more recent addition than print reference works, these guides quickly have become the primary portal through which students and scholars gain access to other parts of the collections in print or electronic format. These guides are maintained by librarians at the individual law schools and are typically updated regularly to add, fix, or remove content. Such guides offer a convenient means of conducting basic and advanced legal research on a wide range of international issues. The guides are written with both beginners and experts in mind. The actual format of the guides varies widely from library to library. Some, like Legal Research on International Law Issues Using the Internet, developed by Lyonette Louis-Jacques (2011a) at the D'Angelo Law Library of the University of Chicago, have a detailed hypertext-based table of contents that links users to specific databases and sources of further information on specific topics. A student or faculty member doing work on international war crime, for example, can use the online Guide to Foreign and International Law to find historical materials from the Nuremberg War Crimes Tribunal established after the Second World War to try Nazi leaders for war crimes against humanity (Louis-Jacques, 2011b).

From the online research guide, two options exist. Both options transport users from the D'Angelo Law Library site to either that of Yale or Harvard University law schools, where the documents themselves are available. At Yale, a selection of sources is available in .html format as part of the Avalon Project maintained at the Lillian Goldman Law Library (2011). At Harvard Law School Library (2011), the Nuremberg Trials Project preserves in digital format an extensive collection of documents, photographs, and trial records from the 1940s. The D'Angelo war crimes guide also offers access to on-going criminal proceedings like the International Criminal Tribunal for the Former Yugoslavia. 
A link takes users directly to the web site of the Hague-based Tribunal, where users can access daily news reports and updates concerning on-going trials and criminal proceedings. Audio and video recordings, some of which are accessible on YouTube, provide access to weekly press briefings and official statements.

The online international legal research guides from Berkeley, Columbia, Duke, Georgetown, Harvard, and Yale reveal similar features to that of the D'Angelo Law Library. One distinctive aspect of these guides is the crossreferencing of each other. In some cases, librarians created these guides collaboratively. For example, the Duke Law Library's guide to international law (2011) includes a link to an online international research tutorial at U.C. Berkeley, which librarians at Duke helped to design. In other cases, the guides take readers to the identical sites and databases, even if the process of finding the links is different. All of them also highlight the holdings in their permanent print collections and offer secure connections to subscription-only services and premium content for which user login and passwords are required. The guides are much more than collections of links, however, since all contain sections offering advice on how to locate the most reliable, accurate, and up-to-date information on specific topics. Researchers use these guides to navigate through data that is enormously complicated, dispersed, and written in many languages. Sections on foreign and comparative law are listed alphabetically by country, while subsections on international law provide links to major institutions, like the United Nations, the International Criminal Court, the World Trade Organization, and the European Court of Justice, as well as non-profit organizations and foundations that are involved with global issues like public health, environmental protection, refugee rights, or international finance.

\section{Databases}

The third major part of an international legal collection is the database. This section examines some of the essential online databases that currently provide the best access to a range of international legal materials. While the print and online guides discussed in the previous sections are often useful starting points when beginning new research, all of the FCIL collections investigated in this study primarily and increasingly contain materials that can be accessed using online databases. These virtual holdings, which comprise millions of individual documents, considerably add to whatever print materials each individual law school owns in its permanent collection. For many contemporary topics, these databases provide most, if not all, of the relevant sources. Many of the databases were created with a wide audience in mind and shaped by the principles of free access. The databases use keyword style search engines to help users locate primary documents, web sites, and other kinds of content. Much of these 
materials are official government issued records available to the general public at no cost. The databases save users the time and effort that would be needed to locate these sources by visiting directly all of the relevant official and institutional sites that publish the information. They also offer means of finding historical legal documents in digital format that otherwise would be difficult to locate. Some of the databases that allow users to download journal articles and law review essays have restricted access. Researchers require library lending privileges for access to certain databases, such as Hein Online. Others require subscriptions to read and download the content. LawInfoChina (www.lawinfochina.com), maintained by a private company and Peking University, is a good example. In such cases, users may need to sign up for trial period membership or receive specific instructions and login information from a reference librarian. Other leading commercial vendors, like WestLaw and LexisNexis, also offer access to international legal resources to their subscribers. They include premium services such as automatic updates and citation generation, which open access sites do not.

The following databases are excellent examples of what an FCIL collection at a U.S. academic law school might look like. Each of these three sources-GLIN, EISIL, and GlobaLex-invariably appeared at or near the top of most of the online reference guides surveyed in this study.

GLIN. At the top of the list of databases on nearly all of the research guides I surveyed is the Global Legal Information Network (GLIN). It was created by the Law Library of Congress in 2004 as a full-text public legal database. A number of its founders were active in the Free Access to Law Movement (Germain, 2011). Its charter mission is "to promote the rule of law within and among nations, facilitating the orderly development of national and international laws, and encouraging mutual understanding among people of diverse legal heritages" (Medina, 2004, p. 605). GLIN's members come from around the world and collaborate towards the goal of building a "state of the art global electronic legal archive" (p. 605). Each jurisdiction contributes standardized metadata in its own official language and in one additional Network lingua franca: English. Users can input search criteria in a variety of languages, including French, Spanish, Portuguese, Arabic, Romanian, Korean, and Chinese (Simplified and Traditional). GLIN depends upon its global partners to provide documents and other relevant materials. Prospective members must apply for admission and agree to adhere to its guiding principles. Some parts of the world are less well represented in GLIN than others and only recently have there been efforts made to recruit more widely outside of the existing membership. Despite these limitations, GLIN is already a powerful research tool in the hands of knowledgeable users. GLIN also offers the possibility of subscribing to an Atom 
web feed to receive regular updates when new documents related to a search inquiry are added to the database.

EISIL. Another important database is the Electronic Information System for International Law (EISIL). It is a partnership between the American Society of International Law and U.C. Berkeley Law School. It was founded in 2000 with the goal of becoming a "'one-stop shopping' site that would guide researchers to high quality international law information on the web" (Watson, 2005, p. 267). It provides access to primary documents, websites, and research guides. One specific feature of EISIL is that it provides short descriptions for each document or web resource, including tips on how to use them effectively. According to Watson (2005), EISIL offers distinct advantages over search engines like Google for finding legal resources, because it is more discriminating in its source selection and offers the value-added feature of entry descriptions (p. 271).

One of the strengths of EISIL is the clarity and organization of its home page, which prominently displays fourteen main international legal categories. The interface is very user-friendly and visually effective. It assists beginning researchers with helpful definitions of international legal terms and has special sections devoted to "Basic Sources," "Historical Materials," and "Treaty Collections." Working through the categories enables users to locate links to international government organizations (IGOs) as well as non-governmental organizations (NGOs). EISIL is designed to supplement international legal collections at libraries where the permanent holdings are limited in certain areas. It also can be incorporated into classroom instruction as a training tool to prepare students for conducting more advanced research. This makes it a good place to start preliminary work on a new subject by browsing through its logically structured web architecture.

GlobaLex. This database emerged as a prototype for conducting international legal research under the direction of NYU law librarian, Mirela Roznovschi, whose influence on the field has already been mentioned. While GlobaLex was clearly designed to support NYU's Hauser Global Law Program, it is, like GLIN and EISIL, available online to the wider public (Kuehl, 2006). It features research guides organized by country and subject. Notably, the international section includes links to organizations such as the African Union and Association of Southeast Asian Nations (ASEAN). There is also a detailed how-to guide written for librarians interested in building their own international legal collections. What is distinctive about GlobaLex is how closely it is connected to its founder, Ms. Roznovschi, who is extensively involved with a wide range of international legal initiatives and who teaches legal research courses outside of the United States in Russia, Hungary, and elsewhere. Because of her deep 
personal involvement in the field, she updates GlobaLex on a regular basis, repairing broken web and enabling error-free access to foreign materials (Roznovschi, 2002). Based on her own impressive description of a typical working day in her book, Towards a Cyberlegal Culture, in which she reportedly checks her email messages to European colleagues at 6 a.m. and the ones from Australia and New Zealand late at night, in addition to working at the NYU legal reference desk and answering student emails about the status of the endangered Siberian tiger, it would seem that she is indeed a very important personal part of the international legal networks surveyed (pp. 3-6).

\section{An Assessment Review: Trends and Challenges}

The results of this study of FCIL collections at twelve public and private U.S. academic schools reveal a variety of notable trends in and significant challenges to the ongoing efforts of professional librarians and information specialists adapting to the digitization of large amounts of increasingly heterogeneous information. The collections under investigation emerged rapidly in the past decade as growing amounts of global legal information became available on-line (Rumsey, 2008a). As more governments committed themselves to making electronic versions of their laws, regulations, and court decisions available to the public, librarians at U.S. academic law schools responded by consolidating these sources into searchable databases and prepared research guides to facilitate their use.

\section{Global Access}

Claire Germain (2011), a professor of law and associate dean for legal information at the University Of Florida Levin College Of Law, writes about this process. Before digitization, accessing international legal information was extremely challenging. Germain argues that the early successes of projects like GLIN and GlobaLex encouraged government justice ministries and other official agencies to accelerate the process of putting legal information online without charging fees for the service. The trend towards free access has, in turn, made it possible for librarians to expand their digital FCIL collections rapidly and at low cost. The existence of public, decentralized databases like GLIN has prompted some governments in Africa, Asia, and the Middle East to participate by providing official documents (Germain, 2011, p. 192). The West African nation of Gabon, one of the countries that recently entered the network, explained its decision to join as part of a larger policy of transparency and good governance. GLIN's Gabon station includes a director responsible for daily management, three legal analysts who prepare the texts for submission, and an administrator who 
handles accounts and digitization (p. 192). The justice ministry of Kuwait even goes so far as to display prominently its GLIN membership status on their official government e-justice website (p. 184). The result of such actions is an expanded and electronically accessible international legal database of growing proportions.

\section{Ensuring Accuracy}

As these databases continue to expand, however, new problems arise in maintaining them and ensuring that the information contained is current and accurate. Building up their international legal collections quickly was a priority for law school librarians who sought to keep pace with the new FCIL programs of study. They relied heavily upon the Internet to connect to the growing range of online guides and databases that came into existence in the past ten years. As these collections mature, some informed observers like Germain (2011) have raised important questions about the quality of the information contained. Some foreign countries, for example, post disclaimers about the documents published online and refer users to printed gazettes and legal code books for the official and authentic versions. Ensuring that online legal information is authentic and protected from error or outside manipulation is an ongoing process towards which a number of governments are working. Relying heavily on free access sources accessible only online, as Raisch (2011) points out, means that these collections are at risk in the event of technical difficulties, broken links, or loss of funding. Subscription-based services that provide access to additional international legal data effectively rent rather than own the materials as part of a permanent print collection. This means that the international legal collections at U.S. academic law schools are often quite substantial and remain susceptible to long-term access issues.

\section{Preserving Knowledge}

In the coming years, preserving all of this new international legal content will be challenging, but it also gives librarians an opportunity to assist in protecting what Germain (2011) calls the "digital heritage of mankind" (p. 195). All digital content is vulnerable to loss and subject to periodic migration from one platform to another. In the case of international legal information, the problem is particularly acute because of its dispersed locations, intricate distribution system, and linguistic complexity. A significant portion of the collections exist online and rely upon external servers to preserve the information. Often there are no print versions in the permanent collection that researchers might consult in the event of Internet service disruption. If librarians are able to figure out effective long-term ways of preserving these materials, the result could well be a valuable record of 
the evolution of international law in the twenty-first century, one that future scholars might find particularly important. If this were the case, then the international legal collections currently maintained by U.S. academic law schools would not just serve a present need but also would become a future resource for studying how globalization is changing the way that our society is organized. Libraries have always served the purpose of storing and preserving knowledge for many generations of use, and there is no reason why this should be any different in the age of electronic information.

\section{Conclusion}

In summation, this study has revealed the central role that librarians have played, and continue to play, in developing FCIL collections and programs of study at some of America's top law schools. As committed information professionals, they have been actively involved in all stages of the process. As teachers, they instruct students in how to conduct international legal research. As information specialists, they prepare research guides and collaborate at a global level with their counterparts in other countries to create powerful new databases containing vast quantities of useful material about how the world is governed. As advocates for open access, they have also helped to create a system of information exchange that is largely free to use, with the important exception of some services that charge fees or require user specific passwords. And as critical observers of the collection building process, librarians continue to offer suggestions for improving the reliability of the international legal information upon which students and scholars depend. Some have raised concerns about the heavy reliance on Internet sources whose authenticity and accuracy cannot easily be determined. For this reason, reference works prepared by experts in the field and regularly revised and updated, like the George Washington Law Review's Guide to International Legal Research, the Max Planck Institute's Encyclopedia of Public International Law, and database systems like GLIN, EISIL, and GlobaLex are likely to remain essential tools.

The international legal collections at U.S. academic law schools surveyed in this study have a lot of information but are not always easy to navigate. FCIL collections as detailed as the ones investigated here are probably best used in consultation with reference librarians who can help users to get good results. These collections are fully operational but are still works in progress. For professional librarians, the task of creating international and foreign legal collections requires a range of skills. These include the ability to evaluate a wide range of foreign-language sources and to work with a number of different legal databases. It also requires librarians to work with the current generation of students who, as "digital natives," are more comfortable using online sources than 
those that remain in print (Wayne \& Lomio, 2005). Another important skill will be the ability to work collaboratively with colleagues not just within the United States but transnationally to achieve their objectives. The result of this work, as some advocates suggest, might be a virtual global legal library in which users could access a wealth of information (Gee, 2003, p. 534). Sharing this information across cultural, territorial, and generational boundaries may well be one of the most important roles that librarians can perform in the twenty-first century.

\section{References}

Balleste, R., Luna-Lamas, S., \& Smith-Butler, L. (Eds.). (2007). Law

librarianship in the twenty-first century. Lanham, MD: Scarecrow Press.

Bernhardt, R. (Ed.). (1992). Encyclopedia of public international law. Amsterdam, The Netherlands: North-Holland.

Bird, R. (2011). Legal information literacy. In R. A. Danner \& J. Winterton (Eds.), The IALL international handbook of legal information management (pp. 115-133). Farnham, England: Ashgate.

Borgman, C. L. (2003). From Gutenberg to the global information infrastructure: Access to information in the networked world. Cambridge, MA: The MIT Press.

Chiang, W.-S. S., \& Price, K. (Eds.). (1992). International access to legislative information: A preliminary investigation. Sarasota, FL: UNIFO Publishers.

Cornell University Law School. (2011). Avon Global Center for Women and Justice. Retrieved from http://ww2.lawschool.cornell.edu/womenandjustice

Duke Law School. (2011). Research methods in international, foreign, and comparative law. Retrieved from http://www.law.duke.edu/curriculum/courseinfo/course?id=76

Duke Law School Library. (2011). International legal research tutorial: Research guides. Retrieved from http://www.law.duke.edu/ilrt/sources_2.htm 
Friedman, L. M. (2011). Erewhon: The coming global legal order. In L. M. Friedman, R. Pérez-Perdomo, \& M. A. Gómez (Eds.), Law in many societies: A reader (pp. 308-316). Stanford, CA: Stanford University Press.

Gee, D. (2003). A comparison of four premier academic law libraries in the United States and the United Kingdom: The findings of a valuable international placement. International Journal of Legal Information, 31(3), 520-534.

George Washington International Law Review. (2011). Guide to international legal research. New Providence, NJ: LexisNexis.

Georgetown University Law Center. (2011). Week one: Law in a global context. Retrieved from http://www.law.georgetown.edu/registrar/bulletin/WeekOne1L1E.htm

Germain, C. M. (2007). Legal information management in a global and digital age: Revolution and tradition. International Journal of Legal Information, 35(1), 134-163.

Germain, C. M. (2011). Digitizing the world's laws. In R. A. Danner \& J. Winterton (Eds.), The IALL international handbook of legal information management (pp. 181-199). Farnham, England: Ashgate.

Harvard Law School. (2011). About ILS. Retrieved from http://www.law.harvard.edu/news/spotlight/ils/about/index.html

Harvard Law School Library. (2011). Nuremberg trials project. Retrieved from http://nuremberg.law.harvard.edu/php/docs_swi.php?DI=1\&text=overvie w.

Haugen, B. (2005). The impact of globalization on law libraries. International Journal of Legal Information, 33(3), 471-478.

Kimbrough, T. (2006). Building a Chinese law collection in the academic law library: Challenges, alternatives, and trends. Legal Reference Services Quarterly, 25(4), 37-69. 
Kuehl, H. F. (2006). GlobaLex: A unique and valuable tool for foreign, comparative, and international law. International Journal of Legal Information, 34(3), 473-482.

Lillian Goldman Law Library. (2011). The Avalon project documents in law, history, and diplomacy. Retrieved from http://avalon.law.yale.edu/subject_menus/imt.asp

Louis-Jacques, L. (2011a). Legal research on international law issues using the Internet. Retrieved from http://www2.lib.uchicago.edu/ llou/forintlaw.html

Louis-Jacques, L. (2011b). War crimes. Retrieved from http://www.lib.uchicago.edu/e/law/intl/warcrimes.html

Martin, H. S. (1992). [ILIN]: A proposal for an international legal information network. In W-S. S., Chiang \& K. Price (Eds.), International access to legislative information: A preliminary investigation (pp. 52-61).

Medina, R. (2004). Worldwide digital legal research: Forging new media for the electronic age. International Journal of Legal Information, 32(3), 604612.

Raisch, M. J. (2011). Shaping electronic collections in foreign, comparative, and international law. In R. A. Danner \& J. Winterton (Eds.), The IALL international handbook of legal information management (pp. 261-280). Farnham, England: Ashgate.

Roznovschi, M. (2002). Toward a cyberlegal culture (2nd ed.). Ardsley, NY: Transnational Publishers.

Rumsey, M. (2008a). Gauging the impact of online legal information on international law: Two tests. Syracuse Journal of International Law and Commerce, 35(2), 201-217.

Rumsey, M. (2008b). Going global: Developing an electronic foreign and international law collection. Trends in Law Library Management and Technology, 18, 31-34, 43-48. 
Rumsey, M. (2009). The skills they need: International and foreign legal research. Legal Reference Services Quarterly, 28(1-2), 133-149. doi:

$10.1080 / 02703190902961510$

Silver, C., Van Zandt, D., \& De Bruin, N. (2008). Globalization and the business of law: Lessons for legal education. Northwestern Journal of International Law \& Business, 28(3), 399-414.

Stanford Law School. (2011). Foreign and international legal research. Retrieved from http://www.law.stanford.edu/program/courses/details/461/Foreign\%20and \%20International\%20Legal\%20Research\%20/

Stanton, T. C. (2010). Globalization and the internationalization of legal education in the United States: An annotated bibliography. Legal Reference Services Quarterly, 29(1), 23-49. doi: $10.1080 / 02703190903554793$

U.C. Berkeley School of Law. (2011). Miller Institute for Global Challenges and the Law. Retrieved from http://www.law.berkeley.edu/mgcl.htm

Watson, J. (2005). EISIL: A gateway to international environmental law on the web. International Journal of Legal Information, 33(2), 267-273.

Wayne, E. V., \& Lomio, P. J. (2005). Book lovers beware: A survey of online research habits of Stanford law students (Research Paper No. 2). Stanford, CA: Robert Crown Law Library.

Wolfrum, R. (Ed.). (2012). The Max Planck Encyclopedia of Public International Law. Oxford, England: Oxford University Press.

Zarins, P., Watson, J. M., Gamble, J. K., Louis-Jacques, L., Stott, P. H., Koh, H. H., \& Slye, R. C. (1995). Broadening access to international law resources through new technology. In J. L. Hargrove (Ed.), Proceedings of the eighty-ninth annual meeting of the American Society of International Law: Structures of world order (pp. 1-18). Washington, DC: The American Society of International Law. 